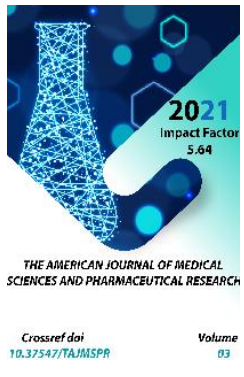

Copyright: Original content from this work may be used under the terms of the creative commons attributes 4.0 licence.

\section{Means And Problems Of Forming A Healthy Lifestyle Among The Population}

Guloyim Sattarovna Avezova

Associate Professor, Public Health Schools, Tashkent Medical Academyuzbekistan

Zarnigor Beshimova

Master's Student, Specialty “Higher Nursing”, Public Health Schools Tashkent Medical Academy, Uzbekistan

Gulshod Sattarovna Avezova

Assistant, Department Of “Physiology”, Uzbek State University Of Physical Culture And Sports, Chirchik, Uzbekistan

\title{
ABSTRACT
}

The health of the population, its preservation and strengthening, an increase in life expectancy and a reduction in mortality have always been and remain the focus of state social policy. However, it is known that human health depends not only on the quality of medical care, but also on many other factors, such as genetic predisposition to certain diseases, the state of the environment and lifestyle. According to experts from the World Health Organization, the combined contribution of medical care and hereditary factors to health is no more than $30 \%$, while $50 \%$ is a healthy lifestyle.

\section{KEYWORDS}

Healthy lifestyle, population, survey, youth.

\section{INTRODUCTION}

A healthy lifestyle (HLS) is a rational lifestyle, an integral feature of which is vigorous activity aimed at maintaining and improving health. A lifestyle that contributes to public and 
individual health is the basis of prevention, and its formation is the most important task of the state's social policy in protecting and strengthening the health of the people. Thus, the formation of a healthy lifestyle is the most important task of the state, since the way of life is a determining factor in health. The formation of a healthy lifestyle is also the task of the health care, social protection and education authorities. According to experts from the World Health Organization (WHO), the combined contribution of medical care and hereditary factors to health is no more than $30 \%$, while $50 \%$ is a healthy lifestyle.

\section{THE MAIN FINDINGS AND RESULTS}

Among the many factors of the environment, socio-hygienic, labor nature, etc., a special place is occupied by the so-called "behavioral factor" in $50 \%$ of cases, which determines the incidence and mortality from diseases caused by bad habits - smoking, alcohol consumption, too fatty and high-calorie. According to WHO, regular physical activity of the appropriate intensity improves the condition of the muscles, as well as the cardiac and respiratory systems, improves the condition of bones and functional health, and reduces the risk of developing hypertension, coronary heart disease, stroke, diabetes, breast and colon cancer, as well as depression. reduces the risk of falls, as well as fractures of the hip and spine and is the basis of energy metabolism and maintenance of normal weight $[1,2]$.

Physical inactivity is the fourth leading risk factor for death in the world. It leads to $6 \%$ of all deaths. Only high blood pressure (13\%) and tobacco use $(9 \%)$ excel in significance. High blood glucose has the same risk level (6\%). An estimated 3.2 million people die each year due to insufficient physical activity.

\section{PURPOSE OF THE STUDY}

Conduct questionnaires among various groups of the population (youth, doctors, patients) on a healthy lifestyle.

\section{MATERIAL AND RESEARCH METHODS}

Sociological: - questioning of the population of different categories of 80 respondents living in Zangiata region, to study the level of medical awareness about a healthy lifestyle

- questioning of medical staff, 68 respondents working in primary health care to study the attitude, level of knowledge and the volume of activities to promote a healthy lifestyle.

The developed structured questionnaire to study the level of medical awareness of the population about a healthy lifestyle included 22 questions, mostly of a closed type. The questionnaire included the following blocks: the study of the main sources and nature of healthy lifestyle, attitude to bad habits, type and nature of nutrition, attitude to sports, and the latter focusing on the relationship with the medical staff and the population.

\section{RESULTS}

Health is the main value of human life; it occupies the highest level in the hierarchy of human needs [6]. Health is one of the important components of the human condition and one of the main factors of social and economic condition. At the same time, health realizes the intellectual, moral, spiritual, physical and reproductive potential, which can exist only in a healthy society.

According to the experts of the World Health Organization (WHO), health is a state of perfect physical, spiritual and social well-being, and not just the absence of disease and physical defects [5]. Therefore, it is customary to evaluate and study health from different angles: 
The field of biology and medicine; physical education and sports; psychological sciences. This moment in the concept of health includes such components as: moral and spiritual wellbeing $[5,6]$. It is customary to consider a model of health with the help of some of its constituents: physical health (physical condition of a person); mental health; social health; moral health.

This is a complex that contains motivational features and a need for information in the sphere of life, which describes the system of values, attitudes and motives of an individual in society. The moral health of a person is associated with spirituality, as well as it is associated with morality, love, mercy and beauty, this is the main condition for teaching and learning motivations for students to maintain a healthy lifestyle. A healthy lifestyle is due to the constant education of a culture of health among students: physical regulation, physiological regulation, psychological regulation, intellectual regulation $[3,4,5,7]$.

It is important to note that today, young people are more or less interested in healthy lifestyle. The majority of young people (74.5\%) prefer to "take care of their health". The second place is taken by taking care of their appearance and figure (62.9\%). However, if among young men only $20.6 \%$ of the respondents prefer the answer "taking care of their health", then among girls already $53.9 \%$ of the respondents. That is, for many young people, health is a tool that allows them to maintain their attractiveness. When analyzing the factors that interfere with maintaining a healthy lifestyle, it can be seen that the most frequent answer among boys and girls is laziness: $14.5 \%$ and $31.6 \%$, respectively. It is followed in frequency by the answer "lack of time" $-11.9 \%$ for boys and $25.5 \%$ for girls. It should be noted that the lack of knowledge and skills of a healthy lifestyle in adults reduces the effectiveness of hygienic education of children. As a result of a violation of the daily regimen and rest, most children develop painful conditions.

So, having considered some criteria for a healthy lifestyle, we can summarize. In this study, it was found that a healthy lifestyle contributes to the strengthening of human health through certain preventive measures. Leading a healthy lifestyle improves emotional well-being, increases efficiency and normalizes the body's vital functions. A healthy lifestyle is a system of reasonable human behavior (moderation in everything, optimal motor regime, hardening, proper nutrition and rejection of bad habits), which provides a person with physical, mental, spiritual and social well-being (i.e. health) in the real environment. environment and active longevity.

A sociological study of the opinions of doctors and patients allows us to conclude that, despite the high degree of confidence in the doctor's recommendations for the formation of a healthy lifestyle, the coverage of the population with consultations is very low. The doctors named the lack of time as the main reason $(80.3 \%)$, which indicates the need to optimize the doctor's working time. The lack of conviction among $35.0 \%$ of doctors in the effectiveness of recommendations shows a low level of doctors' knowledge of the results of scientific research on prevention. Most doctors are aware of the negative impact of their own lifestyle on the implementation of preventive recommendations by patients. $15.1 \%$ of respondents believe that the presence of bad habits in a doctor causes a negative reaction in patients, $44.5 \%$ - reduces the likelihood of fulfilling the recommendations, $20.4 \%$ are sure that it does not decrease if the patient trusts the doctor and only $11.7 \%$ believe, which does not reduce. At the same time, a significant part of doctors (41.6\%), called upon to form a healthy lifestyle among the 
population, do not pay attention to their own health.

Analyzing the information received on the main risk factors for the development of diseases in patients of primary health care (PHC), it is possible to determine the main directions of the information component of the program. Information messages and training seminars should include the following thematic sections: rational nutrition, the impact of bad habits on health and the fight against them, the benefits of physical education and sports, ways to relieve emotional stress and tension. Improve the work of health schools. $64.9 \%$ of patients consider it necessary to carry out such programs. It is especially effective for working with pensioners. This category of patients has the opportunity not only to improve health literacy, but also to consult with doctors of different specialties for free, as well as satisfy the need for communication. Regularly (once every 3 months) carry out special events "Days of Health" with media coverage. These days, patients can take clinical blood tests for free, take an electrocardiogram and get a consultation from a cardiologist, listen to a lecture on a healthy lifestyle. These promotions are also effective for retirees. It is important to form a fashion for a healthy lifestyle. This is especially important for the younger generation. The propaganda materials do not take into account the psychology of the "market" generation with a more individualized consciousness than the older generation, its new consumer subculture, in which the main concept is prestige.

\section{CONCLUSION}

One of the most important indicators of the balance of health and the success of professional activity is the formation of the value and culture of health and the dependence of their formation on such psychological and acmeological characteristics as gender, age, socio-economic status, level of education, profession. The main sources of information on healthy lifestyles are television channels (for $89 \%$ ) and information and visual aids in medical institutions (for $88 \%$ of outpatients). Print media indicate $38-43 \%$, but at the same time, in periodicals, single publications are devoted to the topic of a healthy lifestyle, which are not always relevant and / or scientifically based, since, especially for local and regional publications, it is more profitable to place information of an advertising or sensational nature. than educational materials. According to public opinion, medical workers are practically not sources of information on the formation of a healthy lifestyle (in this context, only 3\% of patients call them).

\section{REFERENCES}

1. Bahromjon Mamatkulov. (2013) Public health and health management. Tashkent: Ilm-Ziyo. (Бахромжон Маматқулов. Жамоат саломатлиги ва соғлиқни сақлашни бошқариш. Тошкент. Илм Зиё-2013.)

2. Vilensky M.Y. (2007) Physical culture and healthy lifestyle of a student: textbook [Text]: textbook / M.Ya. Vilensky, A.G. Gorshkov. - Moscow: Gardariki. - p. 218. (Виленский М.Я. Физическая культура и здоровый образ жизни студента: учебное пособие [Текст]: учебник / М.Я. Виленский, А.Г. Горшков. - М.: Гардарики, 2007. - 218 с.)

3. Kanevskaya T.M. Propagation of the values of a healthy lifestyle as a means of preventing addictions in the student environment of a pedagogical university: theory and practice [Text] / T.M. Kanevskaya, V.A. Sereda // Pedagogical education in Russia. - 2011.- No. 4. - pp. 8795. (Каневская Т.М. Пропаганда ценностей здорового образа жизни как 
средство профилактики зависимостей в студенческой среде педагогического вуза: теория и практика [Текст] / Т.М. Каневская, В.А. Середа // Педагогическое образование в России. - 2011.- № 4. - C.87-95.)

4. T.V. Karaseva. (2013) Technologies of students' education in the sphere of healthy and safe way of life [Text] / T.V. Karaseva, S. Yu. Tolstov, P.A. Kislyakov // Scientific journal of KubSAU, № 91 (07). pp. 3-7. (Карасева Т.В. Технологии образования студентов в сфере здорового и безопасного образа жизни [Текст] / Т.В. Карасева, С.Ю. Толстова, П.А. Кисляков // Научный журнал КубГАУ, № 91 (07), 2013. - С.3-7.)

5. Kachan L.G. (2002) Formation of modern knowledge about health and healthy lifestyles. Novokuznetsk: Publishing house IPK. - p. 76. (Качан Л.Г. Формирование современных знаний о здоровье и здоровом образе жизни. Новокузнецк: Изд-во ИПК, 2002. - 76 с.)

6. Mamatqulov BM, Nodirov T. (2018) Healthy lifestyle and family health. Study guide. - Karshi. (Маматқулов Б.М., Нодиров Т. Соғлом турмуш тарзи ва оила саломатлиги. Ўқув қўлланма. Қарши, 2018.)

7. Укрепление здоровья и

профилактика заболеваний (основные термины и понятия) / Под ред. А.И. Волкова, Р.Г. Оганова. М., 2001. $-287 \mathrm{C}$. 